\title{
FINANCIAL INTERMEDIATION SECTOR IN INDONESIA'S PRODUCTION PYRAMID
}

\author{
Martin P.H. Panggabean
}

\begin{abstract}
This paper investigates the importance of financial intermediation sector in the inter-industry context, using input-output tables from 1995, 2000, 2005, and 2010. Known as matrix triangulation problem, the problem was mathematically categorized as NP-Hard where exact solution to real-world data cannot be ascertained. The algorithm used in this paper was proposed by Chanas-Kobylanski. The computation results confirm that the financial intermediation sector is consistently among the most important sector in the production structure of the Indonesian economy by serving non-negligible input to most sectors in the economy. This paper shows that the sector has mixed record toward small-scale businesses. Financial intermediation sector supports directly and indirectly retail trade, agricultural and food-beverages sectors. The relatively large share of input from financial sector implies the high interest rate charged by banks to the retail trade sector, which in turn reflects high risk associated with Retail Trade (and SMEs in general). Thus tightening and improving efficiency between financial intermediation and retail trade sector will not only increase SMEs participation in the economy but also improve the economic activities in the agricultural and food-beverages sectors which combined contributes to around 19 percent of Indonesia's GDP.
\end{abstract}

Keywords: Financial sector; Input-output table; Indonesia; Triangulation; NP-Hard; Chenery-Watanabe; Chanas-Kobylanski; Meta-heuristic;

JEL Classification: D57; C67; F43; G21;

1 Lecturer, School of Business and Management, Institut Teknologi Bandung (martin.panggabean@sbm-itb.ac.id). The author wishes to acknowledge technical and computational assistance provided by Daniel Allan Juvito and Stefan Batara Panggabean. 


\section{INTRODUCTION}

Financial sector is deemed critical to the functioning of a modern economy (Laeven and Valencia 2008). Indeed, the 1997-1998 financial crises in Indonesia (Radelet and Sachs 1998), near economic meltdowns both in the US (2008) and in Europe (2010) all serve to further reemphasize the importance of the financial sector in an economy (Laeven and Valencia 2008; Brunnermeier 2008).

The attention afforded to the importance of the financial sector is exemplified by the action of the Basel Committee on Banking Supervision (BCBS) which put forward increasingly stringent global banking regulations in the belief that banks' failure may cause systemic risk which can exacerbate or even lead to the collapse of economies at the global level (BlundellWignall and Atkinson 2010).

In Indonesia, following the 1997-1998 near-collapse of the economy, financial intermediation sector (especially banks) has undergone rapid changes. Some of those changes include a reduction in the number of banks, a relaxation of foreign ownership in domestically owned banks, a rapid implementations of Basel regulations, and an adoption of a host of regulations in the insurance industry strengthening capital base. However, the most radical change implemented recently is the separation of banking supervision task from the central bank (Bank Indonesia) (Iyer and Lane 2013). Beginning 2014, an independent Otoritas Jasa Keuangan (OJK, Financial Services Authority) that combined the banking supervision part of Bank Indonesia with the non-banking supervision part of the Ministry of Finance (Bapepam) became effectively operational.

Despite the assumed importance of the financial intermediation sector in an economy, especially the dominance of the banking sub-sector in Indonesia, several questions remain unanswered. First, how should the importance of a sector to the economy be defined? Economic importance as measured by GDP share of a sector does not seem to be adequate since GDP share of a sector is measured from the final demand perspective, thereby ignoring the importance of financial sector services in the entire production (including inter-industry transactions) process. An inter-dependent nature of a modern economy implies that the rest of the economy is using financial intermediation sector services in its production process. Thus an effort must be made to disentangle the inter-dependences among sectors to arrive at a coherent measure of the importance of financial intermediation sector to the economy. To the best our knowledge, this approach (the Chanas-Kobylanski approach) has never been used in the context of the Indonesian economy, thus this paper breaks new ground in terms of methodology.

Second, once a measure of relative importance of a sector can be proposed, this paper empirically calculate the importance of the financial intermediation sector. Emprical section will address questions such as: is financial intermediation sector more important than agricultural sector? How has the importance of the financial intermediation sector changed over time? 
This paper measures and ranks the importance of financial intermediation sector in the Indonesian economy in selected years between 1995 - 2010 period using national input-output data. The findings on the structure of the Indonesia economy will then be used to analyze several government development strategies, especially with respect to its effort in increasing the contribution of small-to-medium scale enterprises to the Indonesia's economy.

The structure of the paper is as follows. After this introductory part, the second part of the paper outlines the theoretical and methodological frameworks used in the paper. Section three explain the computational algorithm, including the framework introduced more than 50 years ago by Chenery-Watanabe (1958), where the empirical and computational framework used at that time was deemed inadequate since it did not reflect the mathematical complexity in finding the optimal solution. Since then various methodological has been and is still being developed. A brief survey of available methods (including the preferred method) is also given in this section, including the outlines the data used for analysis. The fourth part presents computational results of the paper, including its policy implications and recommendation regarding developments of the small and medium enterprises in Indonesia. The final section summarizes and concludes.

\section{THEORY}

The use of an Input-Output table as the basic data for analysis directly assumes that production function of an economy is associated with a specific functional class known as the Leontief function (Varian 1992).

Given the L-shaped isoquant of the Leontief production function, substitution among production factors is not possible. Thus, all production factors needed must enter in fixed proportions. The unavailability of certain input (as supplied by other sectors) directly inhibits production activity since factor substitution is not possible.

The direct implication of the Leontief function is that for production to take place then all input must be available at a certain proportion (Varian 1992). Shortage in the availability of certain factors will limit output in all directly related production activities. In this sense, the most important and critical sectors of an economy are the one whose output is needed as an input by all (or nearly all) production process.

To create an order of importance, a matrix triangulation is needed. However, the published Input-Output table does not directly conform to the required triangle form. Instead, the original ordering of the input-output Table in Indonesia follows the classification of Indonesia's GDP. For example, at the nine-sectors aggregation level, all the primary and extractive sectors (such as agriculture and mining) are listed first. Secondary sectors such as manufacturing and energy production are reported next. Tertiary sectors (services such as retail and wholesale trade, transportation, and hotels) are placed close to the bottom of the reported table. As a result, the input-output table follows the GDP's structure. i.e., ordering of sectors does not reflect the importance of the sector in supporting general production activities. 
The ordering of sectors using primary-secondary-tertiary sector's ordering also fail to take into accounts the issue of connectedness (or interrelatedness) in an economy (Hewings and Jensen 1987). The interrelatedness can be found by rearranging the sectors in such a way so that the skeleton of, and hierarchy in, production system can be seen. Such hierarchy shows a linear dependence and unidirectional flow in a production sector of an economy. Hence an important sector, regardless of its primary-secondary-tertiary distinction, lies at the bottom of the triangle and provides a roughly unidirectional flow to other sectors above it.

Once such matrix is obtained, this paper is concerned about the location (hence the role) of the financial intermediation sector in Indonesia's triangulated Input-Output table. While there are conflicting evidences of whether global financial integrations positively affects growth (Bernini 2011), there is evidence that financial development is linked to future growth (Demirgüç-Kunt and Detragiache 1998). Also, (King and Levine 1993) using data for 80 economies in 30-years period, found that financial development has positive correlation with future rates of economic growth. Yet another research (Christopoulos and Tsionas 2004) concluded that causality runs from financial development to growth. Finally, (Fisman and Love 2004) conducted research on industry level growth. The most pertinent result of this study is that financial development benefits disproportionally those industries with strong growth opportunities, regardless their reliance on external finance. Hence empirical evidence favours the positive role of financial intermediation on the growth of other sectors.

The role of the financial intermediation on the growth of the small-scale enterprises is also a concern to policy-makers as well the public in Indonesia. Financial development leads to sector's growth, but the magnitude of the positive response differs according to the firm size distribution and industry-specific research and development intensity (Beck et al. 2008). All else being equal, Beck et al (2008) shows that industries composed by a greater proportion of small firms grow faster than the others during the process of financial development,

Finally, the role of interest rates is also an important feature in financial development process. In macroeconomics, interest rates play an important role in the inter-temporal allocations of resources (Romer 1996). In inter-industry analysis, the role of interest rates takes additional dimension. For financial intermediaries, translating the macro policy rate into lending rates must take into accounts several factors: the cost of funds (which is highly correlated to policy rate), operating expenses, loan losses and provisions, and finally profits needed to expand its capital base in preparation for planned future growth (Fernando 2006).

Specifically, loan losses and loan provisions must be adjusted to represent risk factors of loans. The risk factors differ among sectors, resulting in some sectors receive more favourable interest rates compared to other sectors. The difference in interest rates for loan, in turn, translated into faster growth. Hence it is important that the relatively important sectors received lower interest rates that can then be translated into faster growth and an improved ability to support other sectors. 


\section{METHODOLOGY}

\subsection{Computational Algorithm}

Chenery-Watanabe (1958) proposed to show the structure of an economy by simultaneously permuting the rows and columns of an input-output matrix of the economy in such a way to maximize the sum of either lower/upper-triangular matrix. For upper triangular matrix, such an arrangement places sector that serves the most sectors in the economy at the top of the (rearranged) matrix, followed by sectors that tend to deliver less output to inter-industry transaction and more toward end users. The bottom of the inverted pyramid will be occupied by sectors that deliver output mostly for final demand.

Triangulation problem is mathematically stated as follows. Let matrix $\mathrm{E}=E_{\mathrm{ij}}$ be an $n \times n$ arbitrary square matrix. Each element $E_{\mathrm{ij}}$ represents monetary value of output of sector $i$ delivered as input to sector $j$. Then the sum of the upper triangular of matrix $E$ is defined as (Campos, Laguna, and Martí 1999; Chanas and Kobylański 1996):

$$
C\left(p_{1}, p_{2}, \ldots, p_{m}\right)=\sum_{i=1}^{m-1} \sum_{j=i+1}^{m} e_{p(i) p(j)}
$$

Where $p$ denotes position of the $i$-th row and $i$-th column in matrix E. Presented this way, triangulation can be seen as a combinatorial optimization achieved by simultaneous permutation of rows and columns of the matrix $E$ to maximize the sum of upper triangular matrix E (Chang et al. 2013).

Exact solution to this optimization of small-sized matrix $\mathrm{E}$ is trivially achieved through an exhaustive permutation of all possible rows combination. In contrast, a square matrix with 10 rows will already have 3,628,800 possible (factorial of 10) rearrangements of rows (and columns), and hence exhaustive permutation impractical since computation time will very large (Martí and Reinelt 2011). As such, the large-sized triangulation problem falls under the category of NP-Hard (Hartmanis 1982).

Chenery-Watanabe (Chenery and Watanabe 1958) put row with the biggest sum at the top of the matrix, followed by row with the next largest sum. The lower-most row will have the smallest row sum. Hence leading to a inverted-pyramid-shaped upper-triangular matrix. This algorithm have been superseded by other algorithms through various improvements. Broad overview of the developments along with the performance of the major algorithms in the available algorithms can be found in two articles written by Marti, Reinelt, Duarte (2012) and Garcia et al. (2006) (Martí, Reinelt, and Duarte 2012; Garcia et al. 2006).

This paper chose to use the Chanas and Kobylanski (Chanas and Kobylański 1996) multistart method ( $C K$, henceforth) as the method to triangulate the Indonesian input-output matrix. Comparisons made among several methods (Martí, Reinelt, and Duarte 2012; Campos et al. 
2001) shows that the CK approach is able to find a high quality solution similar to other metaheuristic approaches, with only negligible differences with the best solution found. In terms of computation time, while not the fastest, the CK method is also quite fast. In this paper, the solutions were arrived at in less than one second for each input-output tables being analyzed. The algorithm was coded in $\mathrm{C}++$ and run on a notebook PC with an i3 processor.

The algorithm of CK was described by Chanas-Kobylanski (1996) as:

\section{$\left(S O R T^{*} \circ R E V E R S E\right)^{*} \circ S O R T^{*}$}

The pseudo-code of the algorithm is the following:

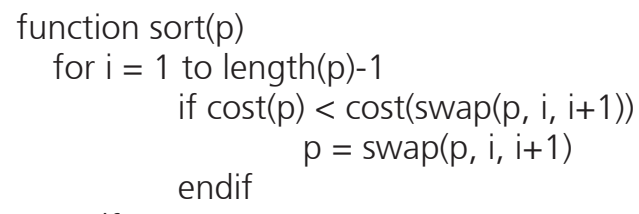

endfor

return $\mathrm{p}$

end

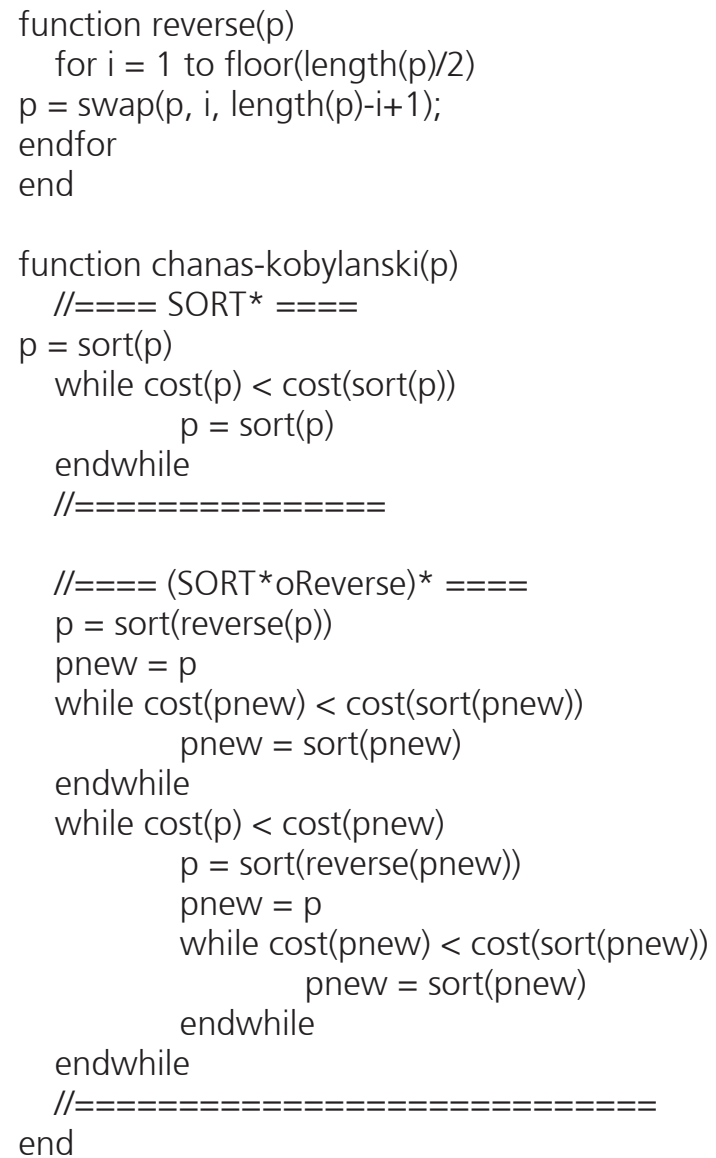


The outline of the algorithm works as follows. Let the initial permutation be P1. Based on this permutation, the objective function value $C(\mathrm{P} 1)$ is calculated. The algorithm then proceed through $\mathrm{P} 1$, and compare the value of $C(\mathrm{P} 1)$ with the value $C(\mathrm{P} 1$ new) where $\mathrm{P} 1$ new is $\mathrm{P} 1$ where two adjacent elements $m$ and $m-1$ (which are the last and second-to-last elements of $\mathrm{P} 1$ ) are swapped. If $C(P 1$ new) is larger than $C(P 1)$, then set P1 as P1new. Using the new P1 ordering, this comparison process is continued as $\mathrm{P} 1(m-1)$ is then compared against $\mathrm{P} 1(m-2)$, and so on. This is the so-called SORT part that results in permutation P1final. Set P1 as P1final, the SORT process is repeated until no further improvement is possible. This is the SORT* stage of the CK algorithm.

The critical part of the CK algorithm appears when the SORT* is followed by the REVERSE stage. The optimal solution P1final from the SORT* is reversed such that the first element in $\mathrm{P} 1$ final become the last element, and vice versa. The new, reversed P1final become the new permutation P2, and the SORT* algorithm begins again. Once the optimal P2 is obtained then it is reversed again, and the algorithm continued until no further increase in objective value is possible.

Three things are important to note. First, the CK method is based on the symmetry property of the LOP (Chanas and Kobylański 1996). If a permutation $\left(p_{1}, p_{2}, \ldots p_{m}\right)$ is an optimal solution to the maximization problem, then the permutation $\left(p_{m^{\prime}} p_{m-1}, \ldots, p_{1}\right)$ is an optimal solution to the minimization problem. Second, the re-starting from a reversed local optimum is expected to induce a diversification component over the search. Third, it is possible to iterate the entire process multiple times and choose which final permutation gives the best possible objective function value.

\subsection{Data}

Data for this paper is based on the World Input-Output Table (WIOT) described in detail in Timmer (Timmer et al. 2015). This data set contains linked Input-output tables for 40 countries comprising 85 percent of the 2008 world GDP. Since inter-linkage among countries is not the focus of this paper, only the Indonesia's part of the WIOT table are being used.

The choice of the WIOT data source has both positive and negative implications. On the negative side, the input-output (IO, henceforth) tables are limited to only 35 sectors, mostly at two-digit ISIC rev. 3 groups. In other words, the Indonesia's economy is divided into 35 sectors. In Timmer (2015) the choice to divide the economy into 35 sectors was dictated by the necessity to impose the same number of sectors across the 40 countries included in the database.

As a comparison, the 2010 (latest) Indonesia's 10 table contains 185 sectors. However, some other countries included in the WIOT database may have reliable data for only at most 35 sectors. Thus Timmer's (2015) choice for 35 sectors was dictated by the lowest common denominator. In practice, however, this paper only uses 33 sectors. Sector 19 ("Sale and repair 
of motor vehicles and motorcycles; retail sale of fuel ") and sector 35 ("Private households with employed persons") have empty values for Indonesia's data. These two sectors are dropped from further analysis. The complete list of the 33 sectors included in the database is given in appendix $\mathrm{A}$.

On the positive side, it must be emphasized that annual time-series data for Indonesia's IO table (and for most countries in the world) is non-existent. Thus, despite the limited number of sectors available for analysis, the construction and availability of annual IO database from the WIOT becomes very important for analyzing structural changes conducted in this paper.

Actual survey-based constructions of IO table for Indonesia were conducted for the years 1995, 2000, 2005, and 2010 (B. P. Statistik 2007, 2000; Statistika 1995; B. Statistik 2015). Input-output tables between the intervening years where actual data were not available were constructed using bi-proportionate adjustment, also called RAS adjustment (Miller and Blair 2009; Parikh 1979). Hence, IO tables for the years 2001, 2002, 2003, 2004 were based on IO table in 2000 but the 10 coefficients are adjusted (through RAS method) to match the actual GDP by expenditures and GDP by sector's value-added. The reader is also referred to Timmer (2015) for further detail regarding the adjustment methodology.

The major motivations for new construction of the 10 table in 1995, 2000, 2005, and 2010 are to incorporate structural changes occurring the economy, as well as to fine-tune definition of sectors as new data becomes available. This paper uses the input-output tables for the year of 1995, 2000, 2005 and 2010.

The IO tables used in this paper are expressed in current US Dollars. Conversion from Indonesia's Rupiah to US Dollars used market exchange rates. The 10 tables are derived from transactions quoted in basic price, defined as producers' price excluding transportation cost (price at fob, free-on-board, excluding trade margin as well as excluding taxes/subsidies). The use of basic price is following international best practice espoused by the United Nations (Dietzenbacher et al. 2013).

There are three distinct ways that the 10 tables can be analyzed. The most direct approach is to use the 33-by-33 inter-industry in its raw form, i.e. in nominal amount as given by the WIOT database. This is the approach that was used in Chenery-Watanabe (1958) and will also be used in this paper.

The second approach (Kondo 2010, 2014) is to convert a raw IO table into its corresponding Leontief matrix. A Leontief coefficient of a particular column in the 10 table is calculated as the proportion of that column with respect to the sum of that particular column (i.e. total input, including primary inputs such as labor and capital). This results in a matrix whose elements are fractions whose values lies between zero and one.

The third approach (Kondo 2014) is to start from Leontief matrix obtained in the second approach. Any element of the Leontief matrix smaller than $1 / \mathrm{n}$ (where $\mathrm{n}$ is the row of the IO matrix used in the analysis) is converted to zero. 
In all three approaches, the main diagonal of the matrices is zeroed. This is to preclude the possibility that a sector can become important only because it is a major buyer of its own product. As stated in the theoretical section, the importance of a sector is defined through its contribution in the production of other sectors.

\section{RESULTS AND ANALYSIS}

In part two it is proposed that, along the Chenery Watanabe (1958) line, Linear Ordering ranking (matrix triangulation) can be used to measure sector's importance in terms of interindustry transactions. It was also established in part two that triangulation of a matrix is an NP-Hard problem, and hence a meta-heuristic model with a multi-start approach should be used. For a relatively small-sized matrix, the Chanas-Kobylanski (CK, henceforth) approach is not disadvantaged compared to other, more recent, approaches. Hence the CK approach is used in this paper. After preliminary data analysis, the empirical importance and rankings of Financial sector between 1995 and 2011 is reported.

\subsection{Preliminary Data Analysis}

Analysis of the raw data from Timmer's (2015) database suggests a declining importance of the financial intermediation sector. Two initial evidences are provided: from the GDP perspective and from the perspective of inter-industry total transaction table.

From the GDP perspective, using 2010 data as a case in point, financial intermediation sector accounts for only 1.65 percent of Indonesia's GDP. This is 0.52 percentage points lower compared to the 2005 GDP contribution of the sector. Thus there is a steady decline in the contribution of financial intermediation sector to the GDP. In contrast, during the same period the share of construction sector has increased by 8.09 percentage points (from 15.81 percent in 2005 to 23.90 percent share of GDP in 2011). Also the contribution of the foodbeverage-tobacco sector has increased by 1.42 percentage points in the same period (with GDP contribution of 10.63 in 2005 to become 12.05 percent GDP share in 2010).

From the inter-industry transaction perspective, a similar picture of declining contribution can also be seen. In 2005, financial intermediation sector provided 3.48 percent of all inputs used in the production. By 2010, contributions of the sector to the inter-industry transactions were down to 2.84 percent (reduced by 0.64 percentage points). Inter-industry transactions in 2010 were dominated by agricultural sector (15.09 percent share of total inter-industry transaction) and mining-quarrying sector (11.65 percent share of total inter-industry transaction).

While both perspectives provide a similar picture of a small and declining share of the financial intermediation sector in the Indonesian economy, the results are valid if it is assumed that GDP share and total inter-industry input share are good indicators of the importance of an 
economic sector. If this assumption is accepted, then financial intermediation sector is ranked 18th in terms of importance from the perspective of GDP share, and ranked 12th in terms of importance from the perspective of contribution to total inter-industry input.

\subsection{Rank of Importance}

This section provides importance ranking on the entire 33 sectors available in the IO tables of the Indonesian economy used in this analysis. As a reminder, part two of this paper proposed that calculation of the ranking uses direct raw data. All elements of the main diagonal of the matrix are set to zero to further emphasize the role of inter-industry transaction in determining rank of importance.

Using the CK approach set forth in the second part of this paper, the relative rankings of financial sector in Indonesia are computed at four points in time: 1995, 2000, 2005, and 2010. Computation time for each of the years took less than one second on an i3 notebook, confirming that CK method is not disadvantaged in terms of speed.

Table 1 shows improvements that are made to the initial value of the upper-triangular matrix after the triangulation procedures take place. In general, Table 1 shows that triangulations have succeeded in performing its task.

\begin{tabular}{|c|c|c|c|c|}
\hline \multicolumn{5}{|c|}{$\begin{array}{l}\text { Table } 1 . \\
\text { Improvement in Linearity Measures Due to Triangulation }\end{array}$} \\
\hline & 1995 & 2000 & 2005 & 2010 \\
\hline Initial Linearity (\%) & 59.5704 & 63.4284 & 59.1612 & 59.7026 \\
\hline Final Linearity (\%) & 86.1119 & 87.6751 & 82.4739 & 82.6626 \\
\hline Change (Final-Initial) & 26.5415 & 24.2466 & 23.3127 & 22.9600 \\
\hline
\end{tabular}

In 1995, for example, index of linearity of the published data (the ratio between value of the upper-triangular matrix to the total value of the matrix) was 59.57 percent. After the triangulation (rearranging of rows and columns) takes place, the index of linearity becomes 86.11 percent, an improvement of 26.54 percentage points. This substantial improvement over the initial (published) arrangement shows that better rearrangements (in the sense of improved triangulation) of rows and columns have taken place.

In general, note that the CK method improved linearity by at least 22 percent (in 2010). However, there is a tendency for improvements linearity index to decline over time. The trend is to be expected because the Indonesian economy (and inter-industry transactions) grows more complex over time. 
Table 2 contains results that show the top five most important sectors on years under consideration. The first part of Table 2 presents sector's rankings based on direct 10 data. Financial intermediation sector ranked fifth in 1995, ranked second in 2000, and ranked first in 2005 and 2010 in terms of importance to the inter-industry transactions, implying that the sector provides substantial amount of inputs to many sectors in the Indonesian economy.

\begin{tabular}{c|l|l|l|l}
\multicolumn{5}{c}{ Top Five Highest-Ranked Sectors After Triangulation } \\
Rank & \multicolumn{1}{|c|}{1995} & \multicolumn{1}{|c}{2.} & \multicolumn{1}{c}{2005} \\
1 & Electricity (17) & Financial Intermediati (27) & Financial Intermediation (27) & Financial Intermediation (27) \\
\hline 2 & Real Estate (28) & Renting of Machinery (29) & Machinery (13) & Real Estate (28) \\
\hline 3 & Pulp, Paper (7) & Mining and Quarrying (2) & Real Estate (28) & $\begin{array}{l}\text { Other supporting transport } \\
\text { activities (25) }\end{array}$ \\
\hline 4 & $\begin{array}{l}\text { Post and } \\
\text { telecommunication (26) }\end{array}$ & Real Estate (28) & Mining and Quarrying (2) & $\begin{array}{l}\text { Post and } \\
\text { telecommunication (26) }\end{array}$ \\
\hline 5 & Financial intermediation (27) & Transport equipment (15) & $\begin{array}{l}\text { Coke, refined petroleum } \\
\text { and nuclear fuel (8) }\end{array}$ & Air transport (24) \\
\end{tabular}

This result is in direct contrast with the simple use of GDP share and total inter-industry share as a measure of importance: while the agricultural sector and the mining-quarrying sector account for 15.09 percent and 11.65 percent share of total inter-industry input, these sectors' importance were eclipsed by financial intermediation sector even though the finance intermediation sector only contribute 2.84 percent to total inter-industry in 2010.

The Chenery-Watanabe (1958) theory proposed rearranging sectors not only in terms of magnitude a sector's contribution to other sectors, but also whether it directly serves many or only few sectors in the economy. Table 3 shows that indeed financial sector serves many sectors.

\begin{tabular}{c|l|c|c|c}
\multicolumn{5}{|c|}{$\begin{array}{c}\text { Table 3. } \\
\text { Support To Other Production Activities }\end{array}$} \\
Sector & \multicolumn{1}{|c|}{ Description } & $\begin{array}{c}\text { GDP } \\
\text { Share (\%) }\end{array}$ & $\begin{array}{c}\text { Inter-industry } \\
\text { Share (\%) }\end{array}$ & $\begin{array}{c}\text { Number of } \\
\text { Sectors } \\
\text { Directly Served }\end{array}$ \\
\hline 1 & Agriculture, hunting, forestry and fishing & 6.95 & 15.09 & 22 \\
2 & Mining and quarrying & 5.40 & 11.65 & 19 \\
23 & Food, beverages and tobacco & 12.05 & 8.27 & 21 \\
27 & Financial Intermediation & 1.65 & 2.84 & 31 \\
28 & Real estate activities & 0.47 & 5.27 & 32 \\
25 & Other supporting transport activities & 0.45 & 5.19 & 24 \\
5 & Leather, leather products and footwear & 0.47 & 0.14 & 9 \\
30 & Public administration and defense & 5.11 & 0.39 & 18 \\
29 & Renting of machinery \& equipment & 2.11 & 0.04 & 10 \\
\hline * Note: negligible amounts of inter-industry transactions (cell with values less than USD 9 millions) have been omitted from the calculations of the last columns.
\end{tabular}


The construction of Table 3 is based on inter-industry table for the year 2010, and serves as an example. Thus the financial intermediation sector output is being used by 31 other sectors in the economy (out of the possible maximum of 32 sectors). The sector that received only negligible input from the financial intermediation sector is the "coke, refined petroleum and nuclear fuel" sector. In contrast, the agricultural sector with 15.09 percent share in total inter-industry transactions serves only 22 other sectors and hence ranked lower in terms of inter-industry importance.

At the other end of the spectrum, those sectors that contribute little to other sectors are leather and leather product sector $(0.14$ percent inter-industry share and directly supplies to nine other sectors), public administration and defense sector ( 0.39 percent inter-industry share and directly supplies to 18 other sectors, mostly with small nominal values), and renting of machinery and equipment sector (0.04 percent inter-industry share and directly supplies to 10 sectors). Public administration sector as well as leather and leather-product sectors serves final demand, and contribute less to inter-industry transactions.

While it is not the main goal of this paper, an important observation will be made regarding the role of the manufacturing sector. Throughout the years under analysis, the manufacturing sector's best performance was when it ranked $23^{\text {rd }}$ in 2005 . Thus the role of manufacturing itself has never been important to date. Given that economic progress is often symbolized by the activity in the manufacturing sector, further research should be done regarding the root causes of this low ranking in inter-industry performance.

\subsection{Financial Intermediation Linkages with SME Sectors}

Despite the importance of the financial intermediation sector, not all sectors was provided enough input from the financial intermediation sector. Thus this subsection will show economic sectors that rely on financial intermediation sector. Table 4 shows share of input obtained from financial intermediation sector in five sectors.

\begin{tabular}{l|c|}
\multicolumn{2}{|c|}{ Table 4. } \\
\hline \multicolumn{2}{|c|}{ Share of Input Obtained from Financial Intermediation Sector } \\
\hline Sector & Share of Intermediate Input (\%) \\
$\begin{array}{l}\text { Real estate activities } \\
\text { Retail trade and repair, except of motor } \\
\text { vehicles and motorcycles; }\end{array}$ & 12.01 \\
$\begin{array}{l}\text { Wholesale trade, except of } \\
\text { motor vehicles and motorcycles }\end{array}$ & 11.48 \\
Agriculture, hunting, forestry and fishing & 11.48 \\
Food, beverages and tobacco & 0.73 \\
\hline
\end{tabular}


Three sectors that use the most input from financial intermediation sector are real estate, wholesale trade, and retail trade. Each of these sectors obtained more than 10 percent of their total intermediate input from financial intermediation. (Intermediate input is defined here as excluding imported input and primary input such as labor and capital).

At this point we need to compare three sectors are populated by micro- and small-scale enterprises (Mourougane 2012). On one hand, retail trade uses substantial amount of input from financial intermediation sector. In contrast, despite having many micro- and small-scale enterprises, agricultural sector utilizes input from financial intermediation only in a minor fashion. A further research on this area is needed as the Indonesian government pushes its financial inclusion efforts forward.

Nevertheless, this paper provides a partial explanation to the contrasting situation between retail trade and agricultural sectors. Further analysis of the 2010 input-output table reveals that retail trade sector directly uses output from agricultural sector (12.86 percent) and foodbeverage sector (17.69 percent) as its major intermediate input. Hence, while only having weak direct linkages, financial intermediation sector indirectly drive growth in both agricultural and food-beverages sectors through its strong involvement in the retail sector. Thus retail sector provides a good entry point for the government policies (through banks) to reach SMEs both directly and directly.

However, the role of the financial intermediation sector toward the retail sector is not uniformly supportive. The rather large (11.48 percent) input of retail trade obtained from the financial intermediation sector can be seen in two different, and competing, perspectives. First, as has been discussed, the large input share confirms the importance of the financial intermediation sector to the retail trade sector's cost structure.

Second, and more importantly going forward, a competing perspective suggests that such a large share of the input from financial intermediation sector may be unwarranted because it can be too high. Data from Bank Indonesia shows that indeed retail trade sector have a large pool of non-performing loans coming from SMEs (Keuangan 2015). Hence banks charge much higher interest rate for loans to SMEs (which corresponds to retail trade sector). Anecdotal evidence suggests that while large corporations were charged around 11 percent interest rate per annum, SME pays interest rate in excess of 20 percent. Thus large input share from financial intermediation sector in the trade and retail sector is a not only a reflection of importance of the financial intermediation sector but also a reflection of risk in the retail trade sector. What exactly need to be done, and what policies need to be in place, will be an exciting field of future research. What this paper has asserted and showed is that financial intermediation sector is one of the most important sector in the Indonesian economy which, directly and indirectly, affects three large employment-generating sectors: retail, agriculture, and food-and-beverages sectors. 


\section{CONCLUSION}

Using Chenery-Watanabe (1958) framework, combined with the Chanas-Kobylanski (1996) solution method, this paper establishes that, despite a trend of declining contribution to the GDP, financial intermediation sector remains one of the most important sector in the Indonesian economy since 1995. Financial sector is one the foundation in Indonesian economic structure, in terms of inter-industry linkages, by serving a non-negligible amount of input to a large number of sectors.

Given the importance of the financial intermediation sector, this paper shows that the financial intermediation sector has mixed record toward small- and medium-scale enterprises. Financial intermediation supports retail trade sector while playing only a negligible role in the cost structure of the agricultural sector. Also, inasmuch as retail trade uses a relatively large share of input from financial intermediation sector, such cost structure implies the high interest rate charged by banks to the sector, which in turn reflects high risk associated with retail trade and SMEs in general.

The analysis in paper suggests further studies in how a more focused government efforts to improve efficiency while reducing risk in the SMEs and in the retail trade sector will not only increase SMEs participation in the economy but also improve the economic activities in the agricultural and food-beverages sectors which the combination of these two sectors contribute to around 19 percent of Indonesia's GDP. 


\section{REFERENCES}

Beck, Thorsten, Asli Demirguc-Kunt, Luc Laeven, and Ross Levine. (2008). "Finance, Firm Size, and Growth." Journal of Money, Credit and Banking. 40 (7). Wiley Online Library: 1379-1405.

Bernini, Michele. (2011). Financial Development and Industrial Structure in Developing and Emerging Economies: A Microeconomic Analysis.

Blundell-Wignall, Adrian, and Paul Atkinson. (2010). Thinking beyond Basel III. OECD Journal: Financial Market Trends 2010 (1). Organisation for Economic Cooperation and Development (OECD): 9-33.

Brunnermeier, Markus K. (2008). Deciphering the Liquidity and Credit Crunch 2007-08. National Bureau of Economic Research.

Campos, Vicente, Fred Glover, Manuel Laguna, and Rafael Martí. (2001). An Experimental Evaluation of a Scatter Search for the Linear Ordering Problem. Journal of Global Optimization. 21 (4). Springer: 397-414.

Campos, Vicente, Manuel Laguna, and Rafael Martí. (1999). Scatter Search for the Linear Ordering Problem. New Ideas in Optimization. McGraw-Hill New York, 331-39.

Chanas, Stefan, and Prezemysław Kobylański. (1996). A New Heuristic Algorithm Solving the Linear Ordering Problem. Computational Optimization and Applications 6 (2). Springer: 191-205.

Chang, Ting Fa Margherita, Livio C Piccinini, Luca Iseppi, and Maria Antonietta Lepellere. (2013). The Black Box of Economic Interdependence in the Process of Structural Change. EU and EA on the Stage. Ital J Pure Appl Math 31: 285-306.

Chenery, Hollis B, and Tsunehiko Watanabe. (1958). International Comparisons of the Structure of Production. Econometrica 26 (4). [Wiley, Econometric Society]: 487-521. doi:10.2307/1907514.

Christopoulos, Dimitris K, and Efthymios G Tsionas. (2004). Financial Development and Economic Growth: Evidence from Panel Unit Root and Cointegration Tests. Journal of Development Economics 73 (1). Elsevier: 55-74.

Demirgüç-Kunt, Asli, and Enrica Detragiache. (1998). Financial Liberalization and Financial Fragility.

Dietzenbacher, Erik, Bart Los, Robert Stehrer, Marcel Timmer, and Gaaitzen De Vries. (2013). The Construction of World Input-output Tables in the WIOD Project. Economic Systems Research 25 (1). Taylor \& Francis: 71-98. 
Fernando, Nimal A. (2006). Understanding and Dealing with High Interest Rates on Microcredit. Asian Development Bank 13.

Fisman, Raymond, and Inessa Love. (2004). Financial Development and Growth in the Short and Long Run.

Garcia, Carlos G, Dionisio Pérez-Brito, Vicente Campos, and Rafael Martí. (2006). Variable Neighborhood Search for the Linear Ordering Problem. Computers \& Operations Research 33 (12), 3549-65. doi:http://dx.doi.org/10.1016/j.cor.2005.03.032.

Hartmanis, Juris. (1982). Computers and Intractability: A Guide to the Theory of NP-Completeness (Michael R. Garey and David S. Johnson). Siam Review 24 (1). Society for Industrial and Applied Mathematics: 90.

Hewings, Geoffrey J D, and Rodney C Jensen. (1987). Regional, Interregional and Multiregional Input-Output Analysis. Handbook of Regional and Urban Economics 1. Elsevier: 295-355.

Iyer, Lakshmi, and David Lane. (2013). Indonesia's OJK: Building Financial Stability.

Keuangan, Otoritas Jasa. (2015). Statistik Perbankan Indonesia. Jakarta: Bank Indonesia.

King, Robert G, and Ross Levine. (1993). Finance and Growth: Schumpeter Might Be Right. The Quarterly Journal of Economics 108 (3). Oxford University Press: 717-37.

Kondo, Yasushi. (2010). A New Method for Triangulation of Input-Output Tables for Comparing Industrial Structures and Investigating Clusters of Industries. Submitted to Economic Systems Research.

- 2014. Triangulation of Input-Output Tables Based on Mixed Integer Programs for InterTemporal and Inter-Regional Comparison of Production Structures. Journal of Economic Structures 3 (1): 1-19. doi:10.1186/2193-2409-3-2.

Laeven, Luc, and Fabian Valencia. (2008). Systemic Banking Crises: A New Database. IMF Working Papers, 1-78.

Martí, Rafael, and Gerhard Reinelt. (2011). The Linear Ordering Problem: Exact and Heuristic Methods in Combinatorial Optimization. In, 17-40. Berlin, Heidelberg: Springer Berlin Heidelberg. doi:10.1007/978-3-642-16729-4_2.

Martí, Rafael, Gerhard Reinelt, and Abraham Duarte. (2012). A Benchmark Library and a Comparison of Heuristic Methods for the Linear Ordering Problem. Computational Optimization and Applications 51 (3): 1297-1317. doi:10.1007/s10589-010-9384-9. 
Miller, Ronald E, and Peter D Blair. (2009). Input-Output Analysis: Foundations and Extensions. Cambridge University Press.

Mourougane, Annabelle. (2012). Promoting SME Development in Indonesia. OECD Publishing. Parikh, Ashok. (1979). Forecasts of Input-Output Matrices Using the R.A.S. Method. The Review of Economics and Statistics 61 (3). The MIT Press: 477-81. doi:10.2307/1926084.

Radelet, Steven, and Jeffrey Sachs. (1998). The Onset of the East Asian Financial Crisis. National bureau of economic research.

Romer, David. (1996). Advanced Macroeconomics. mcgraw-hill companies.

Statistik, B. (2015). 
402 Buletin Ekonomi Moneter dan Perbankan, Volume 19, Nomor 4, April 2017

This page intentionally left blank 